Research Paper

\title{
Alcohol Consumption and Lung Cancer According to Ile349Val Polymorphism in ADH3 Gene: Beyond the Tobacco Smoking Effect
}

\author{
Ana Fernández-Somoano1,2匹\#, Sara M Álvarez-Avellón11,2\#, Ana Souto-García1,2, Jesús Vioque1,3, Eva M
} Navarrete-Muñoz 1,3, Adonina Tardón ${ }^{1,2}$

1. Molecular Epidemiology of Cancer Unit, IUOPA, Universidad de Oviedo. Departamento de Medicina. Oviedo, Asturias, Spain, 33006

2. Spanish Consortium for Research on Epidemiology and Public Health (CIBERESP), Instituto de Salud Carlos III. Madrid, Spain, 28029

3. Public Health Department, Miguel Hernández University, Campus San Juan de Alicante. Sant Joan d'Alacant (Alicante), Spain, 03550

\# These authors contributed equally to this work.

$\triangle$ Corresponding author: Ana Fernández-Somoano. Facultad de Medicina. Área de Medicina Preventiva y Salud Pública. Campus del Cristo s/n. Oviedo 33006. Asturias, Spain. Tel: +34 985106265, Fax: +34 985103545, e-mail: capua.uo@uniovi.es

(C) Ivyspring International Publisher. This is an open access article distributed under the terms of the Creative Commons Attribution (CC BY-NC) license (https://creativecommons.org/licenses/by-nc/4.0/). See http://ivyspring.com/terms for full terms and conditions.

Received: 2016.12.21; Accepted: 2017.03.22; Published: 2017.07.20

\begin{abstract}
Objectives: Smoking is the leading cause of lung cancer. However, several studies have suggested other factors such as alcohol consumption could also play a role through polymorphisms associated with alcohol metabolism. We investigated the association between alcohol consumption and lung cancer according to the lle349Val polymorphism in the alcohol dehydrogenase $3 \mathrm{ADH} 3$ gene.

Methods: We carried out a hospital-based case-control study, a total of 402 incident cases of lung cancer and 383 controls were genotyped for the lle349Val polymorphism by polymerase chain reaction combined with restriction fragment length polymorphism. Alcohol consumption and other variables were measured using questionnaires in personal interviews. We used multiple logistic regressions to estimate adjusted odd ratios using and $95 \%$ confidence intervals.

Results: In multivariate analysis, an increased risk of lung cancer was observed for the highest category of alcohol consumption ( $\geq 30 \mathrm{~g} /$ day), although it does not reach statistical significance $(\mathrm{OR}=1.60,95 \% \mathrm{Cl}: 0.91-2.83)$. Besides, an increased risk of lung cancer was observed in the highest category of alcohol consumption for the Ile/Val genotype compared with the lle/lle genotype (OR=2.35, 95\% Cl: 1.04-5.33).

Conclusions: This study suggests that beyond smoking consumption, a high consumption of alcohol might increase the risk of lung cancer. No clear association was found between alcohol consumption and lung cancer according to the lle349Val polymorphism in $A D H 3$ gene.
\end{abstract}

Key words: Alcohol, Lung Cancer, Polymorphism, Acetaldehyde

\section{Introduction}

Lung cancer was the most common form of cancer worldwide in 2012, with approximately 1.82 million incident cases and 1.59 million deaths due to lung cancer [1]. In Spain alone, lung cancer caused 21,487 deaths [2].

Approximately $80-90 \%$ of lung cancer cases are related to smoking [3]. However, other factors such as genetic susceptibility, diet, and alcohol consumption may play a role in the individual variability. In fact, worldwide around 5.5\% of all cancer cases and 5.8\% of total cancer deaths were attributable to alcohol consumption [4]. Alcohol consumption is a known risk factor for several cancer sites such as the oral cavity, pharynx, larynx, esophagus, liver, colorectal 
and female breast, although its role in lung cancer risk is still controversial [5-7]. In 1988, the International Agency for Research on Cancer concluded that "there are enough evidences that alcoholic beverages are carcinogenic in humans" [8]. Alcohol might act as a carcinogenic agent by acetaldehyde, first metabolite of alcohol oxidation, classified as carcinogenic in humans [9], and by altering single nucleotide polymorphisms in genes that are involved with alcohol metabolism or DNA damage repair. Differences in individual lung cancer susceptibility may thus be the result of varying acetaldehyde exposure owing to genetic variants in the alcohol metabolism pathways.

Alcohol dehydrogenases (ADHs) are enzymes that oxidize ethanol to acetaldehyde, and seven ADHs have been identified in humans [10]. One of the functionally important polymorphic sites for $A D H 3$ is Ile349Val, which causes an amino acid change from isoleucine (Ile) to valine (Val). Compared with the wild-type allele (349Ile), the variant allele (349Val) shows decreased ethanol oxidation by about 2.5 -fold [11]. Therefore, the 349Ile allele produces acetaldehyde (a well-known carcinogenic agent) at higher rates, thus increasing exposure time to the carcinogenic effects of acetaldehyde. Individuals who possess the more active variant (349lle) then have a greater risk of developing alcohol-related cancer [12-14].

In Western populations, epidemiological studies on the association between the Ile349Val polymorphism in the $A D H 3$ gene and cancer risk have shown inconsistent results [15-20]. Only two studies have examined the Ile349Val polymorphism in the $A D H 3$ gene and the risk of developing lung cancer, but no association was found $[7,21]$.

We used data from the CAPUA (Cáncer de Pulmón en Asturias [Lung Cancer in Asturias], Spain) study, a hospital-based case-control study of lung cancer carried out in four hospitals in the Asturias region of Spain [22-28], to examine the effect of alcohol consumption on lung cancer risk according to the Ile349Val polymorphism in the ADH3 gene.

\section{Material and Methods}

Details of the CAPUA hospital-based case-control study have been previously described [22-28]. Briefly, a total of 877 incident lung cancer cases aged 30-85 years were recruited and interviewed in four main hospitals of Asturias in northern Spain from October 2000 to December 2010. Patients with primary cancer other than lung cancer in the last 5 years were excluded. All cases were newly diagnosed, previously untreated, and histologically confirmed with the exception of those with advanced stage IV disease for whom surgery is not appropriated, and therefore did not have histological confirmation. The diagnosis of such few cases was confirmed by the oncologist and they were defined as "Clinical Diagnosis". A total of 840 controls were selected from the same hospitals among patients with unrelated diseases. Controls were individually matched to the cases in terms of sex, age ( \pm 5 years), and hospital. The main disease diagnoses of the control series were as follows: $41.1 \%$ inguinal and abdominal hernias (ICD [International Classification of Diseases]-10: K40-K46); 32.5\% injuries (ICD-10: S00-S99); 8.8\% appendicitis (ICD-10: K35); and 13.3\% intestinal obstructions (ICD-10: K56, K57, K60). The study was approved by the regional ethical committee of Asturias, and written consent was obtained from each participant. In 2010 the CAPUA Study was included in the ILCCO (International Lung Cancer Consortium, http://ilcco.iarc.fr) and SYNERGY group (http://SYNERGY.iarc.fr) from the International Agency for Research on Cancer [29, 30].

All 877 cases and 840 controls were Caucasian. Blood or buccal cell samples were obtained from 872 $(99.43 \%)$ cases and $825(98.21 \%)$ controls. After excluding samples because of problems in DNA extraction or difficulties in genotyping mainly because of poor quality DNA, a total of 402 cases and 383 controls were finally genotyped for the Ile349Val polymorphism in the ADH3 gene, and included in final analysis of this study.

\section{Data collection}

Information about known or potential lung cancer risk factors was personally collected by trained interviewers using computer-aided structured questionnaires during the first admission to hospital for diagnosis. The questionnaires collected information from the participants about age, sex, sociodemographic characteristics, tobacco history, diet (including alcohol consumption), occupation, and personal and family (first-degree relatives) history of cancer.

Alcohol consumption and dietary intake were evaluated using a semi-quantitative food frequency questionnaire (FFQ) completed at an interview. The FFQ was an adapted version of the questionnaire by Willet et al. [31] and validated in an adult Spanish population [32-34]. The subjects were asked to report how often, on average, they had consumed 127 food items over the previous 5 years. Serving sizes were specified for each food item. The questionnaire offered nine options for the frequency of consumption for each food, ranging from never or less than once a month to six or more times per day. Nutrient values for each food in the questionnaire were obtained from 
the food composition tables of the US Department of Agriculture and other Spanish sources [35, 36]. Energy intake in kcals/day was estimated for each participant. Vegetable and fruit intakes in grams per day were derived from the FFQ by summing the items of these groups. The reproducibility and validity of this FFQ is comparable to other widely used FFQs [31, 37-40]. The average of correlation coefficients between nutrient intakes estimated using prospectively collected diet records and those estimated with the FFQ were 0.47 for validity and 0.40 for reproducibility [41]. This FFQ also showed satisfactory biochemical validity compared with plasma levels of carotenoids and vitamin $C[33,34]$. Alcohol consumption and dietary intake were available on 297 cases and 292 controls among the study participants.

To measure total alcohol intake, the FFQ evaluated the following types of alcoholic drinks: red wine $(125 \mathrm{~mL})$, white wine $(125 \mathrm{~mL})$, beer $(200 \mathrm{~mL})$, sherry $(50 \mathrm{~mL})$, hard cider $(125 \mathrm{~mL})$, sweet spirits $(30$ $\mathrm{mL}$ ), and brandy, gin, rum, whiskey, and vodka (40 $\mathrm{mL}$ ). The total alcohol intake in grams per day was obtained by summing the intake of alcoholic drinks and was grouped into four categories based on non-drinkers and tertiles of energy-adjusted intake of alcohol among controls. The energy-adjusted intake was computed using the residual method, in which each nutrient was regressed on total calories, and the population mean was then added back to the calculated residuals [31]. We excluded subjects with extreme values for mean daily energy intake $(<500$ and $>3500 \mathrm{kcal} /$ day for women, $<800$ and $>4000$ $\mathrm{kcal} /$ day for men) which indicate misreporting [40].

Study subjects were defined as never-smokers if they had smoked less than 100 cigarettes in their lifetime; under other conditions, they were defined as ever-smokers. Ever-smokers were additionally classified as current smokers if they had smoked at least one cigarette per day along the previous 6 months or longer. Participants who had smoked regularly in the past but had stopped smoking at least 1 year before they were interviewed were defined as former smokers; finally, individuals who had stopped smoking less than 1 year before the interview were defined as current smokers. Ever-smokers were asked about the duration (years) that they had smoked at least one cigarette a day and how many cigarettes they consumed on average per day. Besides, smoking was characterized in terms of pack-years (PY), which is defined as the number of packs of cigarettes smoked per day times the number of smoking years. Subjects were categorized as light $(<36$ PY) or heavy ( $\geq 36$ PY) smokers based on mean cumulative tobacco consumption in the control group.

\section{Genotype determination}

Polymerase chain reaction (PCR) combined with restriction fragment length polymorphism was used to determine the ADH3 genotypes. Genomic DNA was extracted from peripheral blood samples or exfoliated buccal cells, as previously described [42]. For quality control, genotyping was repeated randomly in at least $5 \%$ of the samples, and two of the authors independently reviewed all the results. A quality control of 50 blood and mouthwash samples from the same participants was used to confirm the reliability of the genotyping results using the mouthwash samples. No differences were found in either of the quality controls. PCR reactions were performed in a total volume of $10 \mu \mathrm{L}$ containing $20 \mathrm{ng}$ of genomic DNA, $0.25 \mathrm{mM}$ of deoxyribonucleotide triphosphate (Ecogen, Biologia Molecular S.L., Madrid, Spain), 0.2 units of Taq polymerase (Biotools, Inc., Madrid, Spain), and 2.5 pmol of each primer in 1 $\times$ PCR buffer (Sigma-Aldrich Co., Madrid, Spain). The primers used for the amplification of $A D H 3$ were $(\mathrm{F})$ CAG TTA TAG CAG TCT GGA ATG CA and (R) CCG CTA CTG TAG AAT ACA AAG CA, and the PCR conditions were 30 cycles of $94^{\circ} \mathrm{C}$ for $30 \mathrm{~s}, 68^{\circ} \mathrm{C}$ for $30 \mathrm{~s}$, and $72^{\circ} \mathrm{C}$ for $1 \mathrm{~min}$. The reverse primer was designed to introduce a recognition site for the restriction enzyme $\underline{S s p I}$ (Quimigen S.L., Madrid, Spain) by replacing an A with a G. A $5-\mu \mathrm{L}$ aliquot of each PCR product was digested overnight at $37^{\circ} \mathrm{C}$ with 0.4 units of $S s p \mathrm{I}$. The products were separated on agarose (CONDA Laboratories, Madrid, Spain) gels and stained with ethidium bromide (Merck KGaA, Madrid, Spain). To verify that the data obtained by restriction fragment length polymorphism were coincident with the allele sequence, representative fragments were sequenced (data not shown).

\section{Statistical analysis}

Tests for Hardy-Weinberg equilibrium among controls were conducted using observed genotype frequencies and a chi-square test with one degree of freedom. Univariate analysis was first performed to compare the distribution of age and sex and the frequencies of alleles and genotypes. The differences in the distribution between cases and controls were tested using the chi-square test for categorical variables and the $t$ test for continuous variables.

Crude odd ratios (ORs) and confidence intervals were calculated using Wolf's method [43]. Multivariate unconditional logistic regression analysis with adjustment for age, sex, and cigarette smoking in PYs was performed to calculate adjusted ORs and 95\% confidence intervals (CIs). The models were made based on the variables with a level of significance of $p<0.2$ in the univariate analysis while 
those with a level of significance of $p<0.1$ were maintained in the model as part of the likelihood ratio test. Variables were included in the final models if they modified the coefficients more than $10 \%$. All statistical analyses were conducted using Stata 12.1 software (Stata Corporation, College Station, TX, USA).

\section{Results}

Table 1 shows the distribution of the main characteristics of cases and controls. Cases showed a markedly higher consumption of tobacco smoking than controls (61.93 vs. 35.35 mean of PY), higher mean daily energy ( 2434.49 vs. 2286.65 kcals/day) and lower vegetable intake (122.78 vs. $152.21 \mathrm{~g} /$ day). Squamous cell carcinoma was the main histological type of lung cancer $(39.8 \%)$ and adenocarcinoma the second $(28.1 \%)$ in cases.

Table 1: Characteristics of lung cancer cases and control patients in CAPUA study.

\begin{tabular}{|c|c|c|c|}
\hline Variable & $\begin{array}{l}\text { Cases (402) } \\
\mathrm{n}(\%)\end{array}$ & $\begin{array}{l}\text { Controls }(383) \\
\text { n }(\%)\end{array}$ & p-value ${ }^{a}$ \\
\hline \multicolumn{4}{|l|}{ Gender } \\
\hline Male & $354(88.06)$ & $332(86.68)$ & \\
\hline Female & $48(11.94)$ & $51(13.32)$ & 0.562 \\
\hline Age (years), mean (SD) & $65.77(10.48)$ & $63.15(11.50)$ & 0.001 \\
\hline Pack-years (PY), mean (SD) & $61.93(35.34)$ & $35.35(30.38)$ & $<0.001$ \\
\hline Never & $29(7.21)$ & $106(27.68)$ & $<0.001$ \\
\hline$<36$ & 75 (18.66) & $165(43.08)$ & \\
\hline$\geq 36$ & $298(74.13)$ & $112(29.24)$ & \\
\hline \multicolumn{4}{|l|}{ Smoking status } \\
\hline Never & $29(7.21)$ & $106(27.68)$ & \\
\hline Ever & $373(92.79)$ & $277(72.32)$ & $<0.001$ \\
\hline Former & $188(47.00)$ & 159 (41.95) & \\
\hline Current & $182(45.50)$ & $114(30.08)$ & $<0.001$ \\
\hline $\begin{array}{l}\text { Alcohol consumption (g/day) } \\
\text { mean (SD) }\end{array}$ & $30.40(50.89)$ & $23.69(38.47)$ & 0.072 \\
\hline Non-drinker $(<0.1)$ & 65 (21.89) & 57 (19.59) & \\
\hline $0.1-9.9$ & $67(22.56)$ & $91(31.27)$ & \\
\hline $10-29.9$ & $76(25.59)$ & $76(25.77)$ & \\
\hline$\geq 30$ & 89 (29.97) & $68(23.37)$ & 0.074 \\
\hline Calories, ${ }^{b}$ mean (SD) & $\begin{array}{l}2434.49 \\
(918.76)\end{array}$ & $\begin{array}{l}2286.65 \\
(695.84)\end{array}$ & 0.028 \\
\hline $\begin{array}{l}\text { Vegetable intake (g/day) }{ }^{b} \text {, mean } \\
\text { (SD) }\end{array}$ & $122.78(99.05)$ & $152.21(133.02)$ & 0.002 \\
\hline Fruit intake $(\mathrm{g} / \text { day })^{\mathrm{b}}{ }^{\text {, mean }(\mathrm{SD})}$ & $260.63(197.70)$ & $248.95(213.35)$ & 0.492 \\
\hline \multicolumn{4}{|l|}{ Family history of cancer } \\
\hline No & $219(57.03)$ & $232(61.87)$ & \\
\hline Other cancer & $128(33.33)$ & $119(31.73)$ & \\
\hline Lung cancer & $37(9.64)$ & $24(6.40)$ & 0.186 \\
\hline Missing values & 18 & 8 & \\
\hline \multicolumn{4}{|l|}{ Histological type } \\
\hline $\begin{array}{l}\text { Squamous cell } \\
\text { carcinoma }\end{array}$ & $160(39.80)$ & & \\
\hline Adenocarcinoma & $113(28.11)$ & & \\
\hline Small cell carcinoma & 77 (19.15) & & \\
\hline Large cell carcinoma & $11(2.74)$ & & \\
\hline Non-differentiated & $31(7.71)$ & & \\
\hline Othersc & $4(1.00)$ & & \\
\hline Clinical diagnosis & $6(1.49)$ & & \\
\hline
\end{tabular}

We estimated the frequency of Ile349Val polymorphism in the $A D H 3$ gene in lung cancer patients and controls to evaluate its association with the risk of lung cancer. The genotype distribution for the single nucleotide polymorphism studied was consistent with the Hardy-Weinberg equilibrium. The proportion of the ADH3 349Val allele and the Val/Val genotype in $A D H 3$ was similar among cases and controls (Table 2). No association was found between the $A D H 3$ Ile349Val polymorphism and lung cancer risk; compared with the wild genotype Ile/Ile, the adjusted ORs for $\mathrm{Val} / \mathrm{Val}$ genotype and Val-carriers were 0.95 (95\% CI, 0.52-1.75) and $0.84(95 \% \mathrm{CI}$, $0.57-1.24$ ), respectively (Table 2 ).

Table 2: Genotype distribution of ADH3 lle349Val polymorphism and adjusted ORs for lung cancer in CAPUA Study

\begin{tabular}{|c|c|c|c|c|c|}
\hline$A D H 3$ genotype & $\begin{array}{l}\text { Cases } \\
(n=402) \\
n(\%)\end{array}$ & $\begin{array}{l}\text { Controls } \\
(\mathrm{n}=383) \\
\mathrm{n}(\%)\end{array}$ & p-value & $\begin{array}{l}\text { Crude } \\
\text { OR }\end{array}$ & $\begin{array}{l}\text { Adjusted } \\
\text { OR } \\
{[95 \% \mathrm{CI}]^{\mathrm{b}}}\end{array}$ \\
\hline Ile/Ile & $157(39.05)$ & $141(36.81)$ & & Reference & Reference \\
\hline Ile/Val & $194(48.26)$ & 196 (51.17) & 0.518 & 0.89 & $\begin{array}{l}0.82 \\
{[0.55-1.22]}\end{array}$ \\
\hline Val/Val & $51(12.69)$ & $46(12.01)$ & & 1.00 & $\begin{array}{l}0.95 \\
{[0.52-1.75]}\end{array}$ \\
\hline Val-carriers & 245 (60.95) & $242(60.95)$ & & 0.91 & $\begin{array}{l}0.84 \\
{[0.57-1.24]}\end{array}$ \\
\hline $\begin{array}{l}\text { Frequency of } \\
\text { Val allele }\end{array}$ & 0.37 & 0.38 & & & \\
\hline
\end{tabular}

Table 3 presents the association between alcohol consumption and lung cancer risk. An increased risk of lung cancer was observed in the highest category of alcohol consumption ( $\geq 30 \mathrm{~g} /$ day), although it was not statistically significant (OR=1.60, 95\% CI, 0.91-2.83) (Table 3).

Table 3: Alcohol consumption and lung cancer risk by histology type in CAPUA Study

\begin{tabular}{lllll}
\hline $\begin{array}{l}\text { Alcohol } \\
\text { consumption } \\
\text { (g/day) }\end{array}$ & \multicolumn{2}{l}{$\begin{array}{l}\text { Cases/Controls } \\
\text { Adjusted OR [95\% CI] }\end{array}$} \\
\cline { 2 - 5 } & All cases & $\begin{array}{l}\text { Squamous } \\
\text { cell } \\
\text { carcinoma }\end{array}$ & Adenocarcinoma & $\begin{array}{l}\text { Small cell } \\
\text { carcinoma }\end{array}$ \\
\hline $\begin{array}{l}\text { Non drinker } \\
(<0.1)\end{array}$ & $65 / 57$ & $24 / 57$ & $23 / 57$ & $10 / 57$ \\
$0.1-9.9$ & 1.00 & 1.00 & 1.00 & 1.00 \\
& $67 / 91$ & $28 / 91$ & $21 / 91$ & $11 / 91$ \\
& 0.67 & 0.85 & $0.52[0.24-1.10]$ & 0.72 \\
$10-29.9$ & {$[0.38-1.18]$} & {$[0.39-1.84]$} & & {$[0.25-2.05]$} \\
& $76 / 75$ & $23 / 75$ & $23 / 75$ & $21 / 75$ \\
& 0.89 & 0.74 & $0.72[0.34-1.54]$ & 1.54 \\
$\geq 30$ & {$[0.50-1.58]$} & {$[0.33-1.67]$} & & {$[0.59-4.05]$} \\
& $89 / 68$ & $43 / 68$ & $23 / 68$ & $11 / 68$ \\
& 1.60 & 2.34 & $1.08[0.51-2.30]$ & 1.35 \\
& {$[0.91-2.83]$} & {$[1.10-4.96]$} & & {$[0.47-3.89]$} \\
\hline
\end{tabular}

aAdjusted for age, gender, cigarette smoking in pack years (continuous), energy intake (calories). 
When analyzing alcohol consumption according to cigarette smoking in pack years, a clear effect modification was observed, although the interaction between both variables was not statistically significant and the correlation was low. The highest increase in lung cancer risk was found for individuals in the higher categories of alcohol consumption $(\geq 30$ $\mathrm{g} /$ day) and tobacco ( $\geq 36 \mathrm{PY})$, being the risk increased 22.75-fold (OR $=22.75 ; 95 \%$ CI 7.92-65.36).

Table 4: Alcohol consumption and lung cancer risk modified by pack-years in CAPUA Study

\begin{tabular}{llll}
\hline $\begin{array}{l}\text { Alcohol } \\
\text { consumption } \\
\text { (g/day) }\end{array}$ & \multicolumn{2}{l}{$\begin{array}{l}\text { Cases/Controls } \\
\text { Adjusted OR [95\% CI }]^{\mathbf{a}}\end{array}$} \\
\cline { 2 - 4 } Non drinker $(<0.1)$ & $\mathbf{N e v e r}$ & $<36$ & $\geq 36$ \\
\hline & $12 / 23$ & $10 / 19$ & $43 / 15$ \\
$0.1-9.9$ & $6 / 27$ & $1.91[0.61-6.01]$ & $14.49[4.94-42.50]$ \\
& $0.49[0.15-1.64]$ & $14 / 42$ & $47 / 22$ \\
$10-29.9$ & $3 / 19$ & $14 / 30$ & $9.46[3.28-27.30]$ \\
& $0.43[0.10-1.86]$ & $2.45[0.80-7.47]$ & $10.68[3.81-29.93]$ \\
$\geq 30$ & $2 / 17$ & $18 / 34$ & $69 / 17$ \\
& $0.58[0.10-3.22]$ & $3.03[1.03-8.89]$ & $22.75[7.92-65.36]$ \\
\hline
\end{tabular}

aAdjusted for age, gender, energy intake (calories).

When the association between alcohol consumption and lung cancer was analyzed by the Ile349Val polymorphism (Table 5), we found a statistically significant higher risk of lung cancer among Ile/Val heterozygotes in the highest category of alcohol consumption (reference category Ile/Ile category) (OR=2.35, 95\% CI, 1.04-5.33). A higher risk of lung cancer was also found among Val-carriers, although the risk was not statistically significant $(\mathrm{OR}=1.89,95 \% \mathrm{CI}, 0.92-3.88)$.

Table 5: Alcohol consumption and lung cancer risk stratified byAHD3 genotype in CAPUA Study

\begin{tabular}{|c|c|c|c|c|}
\hline \multirow{2}{*}{$\begin{array}{l}\text { Alcohol } \\
\text { consumption } \\
\text { (g/day) }\end{array}$} & \multicolumn{4}{|c|}{$\begin{array}{l}\text { Cases/Controls } \\
\text { Adjusted OR }[95 \% \mathrm{CI}]^{a}\end{array}$} \\
\hline & Ile/Ile & Ile/Val & Val/Val & Val carriers \\
\hline \multirow{2}{*}{$\begin{array}{l}\text { Non drinker } \\
(<0.1)\end{array}$} & $29 / 21$ & $29 / 30$ & $7 / 6$ & $36 / 36$ \\
\hline & 1.00 & 1.00 & 1.00 & 1.00 \\
\hline \multirow[t]{3}{*}{$0.1-9.9$} & $22 / 32$ & $37 / 52$ & $8 / 7$ & $45 / 59$ \\
\hline & 0.52 & 0.81 & 0.58 & 0.77 \\
\hline & [0.20-1.38] & [0.36-1.84] & [0.11-3.20] & [0.38-1.59] \\
\hline \multirow[t]{3}{*}{$10-29.9$} & $31 / 30$ & $32 / 36$ & $13 / 9$ & $45 / 45$ \\
\hline & 0.58 & 1.20 & 0.90 & 1.15 \\
\hline & [0.23-1.47] & [0.51-2.80] & [0.18-4.51] & [0.55-2.41] \\
\hline \multirow[t]{3}{*}{$\geq 30$} & $36 / 20$ & $46 / 35$ & $7 / 13$ & $53 / 48$ \\
\hline & 1.21 & 2.35 & 0.56 & 1.89 \\
\hline & [0.47-3.15] & [1.04-5.33] & [0.11-2.95] & [0.92-3.88] \\
\hline
\end{tabular}

aAdjusted for age, gender, cigarette smoking in pack years (continue), energy intake (calories).

\section{Discussion}

In this study, we show some evidence that alcohol consumption at levels higher than $30 \mathrm{~g} /$ day might increase the risk of lung cancer independently of tobacco smoking. In view of our results, we cannot confirm or rule out a possible association between Ile349Val polymorphism in ADH3 gene and lung cancer risk by alcohol consumption.

The Val variant allele results in a 2.5-fold reduction in the oxidation rate of alcohol to acetaldehyde [11]. Thus, the wild-type allele and wild-type genotype Ile/Ile could be related to an increased risk of developing lung cancer because of increased levels of exposure of acetaldehyde, to tissues. In addition, it has also been reported that after alcohol intake, blood acetaldehyde concentrations were significantly higher in individuals with the wild-type allele Ile compared to individuals lacking this allele and it has been shown that acetaldehyde breath levels were proportional to acetaldehyde blood levels $[11,44]$. Therefore, exposure to a higher acetaldehyde concentration in the lower respiratory tract may play a critical role in alcohol-related carcinogenesis. This hypothesis is consolidated by the results obtained by Yang et al. [45], where Caucasians with wild-type genotype Ile/Ile showed higher pulmonary ADH activity and increased acetaldehyde-DNA adduct levels than individuals with variant genotype $\mathrm{Val} / \mathrm{Val}$. Thus, Yang et al. suggested that wild-type allele Ile could be considered a risk factor for lung cancer.

Several studies have reported that the wild-type genotype of the $A D H 3$ gene may increase the risk of different tumor types, including cancer of the oropharynx, larynx, esophagus, liver, head, and neck $[15,16,46]$. Other studies, however, did not find such an association $[18,19,47,48]$. The number of studies in lung cancer is very limited. One case-control study in western New York did not find any association between the Ile349Val polymorphism in the ADH3 gene and the risk of developing lung cancer [7]. Another case-control study in Japan failed to confirm a connection between the Ile349Val polymorphism in the $A D H 3$ gene and the development of lung cancer [21]. The results of the present study were likewise unable to demonstrate an association between the Ile349Val polymorphism in the ADH3 gene and lung cancer risk.

On the other hand, a non-significant higher risk of lung cancer was suggested in the highest category of alcohol consumption ( $\geq 30 \mathrm{~g} /$ day). This result is in agreement with the findings of Minegishi et al. [21] and Rohrmann et al. [49]. Before confirming an effect of alcohol consumption, we should take into account a potential residual confounding effect by cigarette smoking, bearing in mind the clear effect-modification found. We were not able to evaluate the effect of alcohol in nonsmokers owing to the insufficient sample size in our population subgroup. Thus, according to two reviews $[12,50]$, 
one meta-analysis [51], and one pooled analysis [52], the current evidence is insufficient to confirm an association between alcohol and lung cancer risk.

Furthermore, our results showed an association between lung cancer and the Ile/Val genotype, however we cannot rule out the possibility that this result could be due to chance because of the multiple comparisons considered or by tobacco residual confounding. Studies carried out by Minegishi et al. [21] and Freudenheim et al. [7] did not find a clear association between Ile349Val polymorphism in ADH3 gene and lung cancer risk by alcohol consumption. These findings should be investigated in more detail in further studies, considering larger sample sizes and alternative genotyping techniques.

The main strengths of our study are the high number of eligible cases, the reasonably large sample size from a homogeneous population of comparable descent, and the fact that all of our control subjects were under Hardy-Weinberg equilibrium. Furthermore, the whole of our cases were pathologically confirmed with the exception of 6 treated as lung cancer without need of pathologic confirmation, and high quality control for genotyping was applied. Our estimates for alcohol consumption were adjusted for smoking consumption and several other factors, such as energy and vegetable intake, were estimated by validated FFQ. Our study may also have some limitations. The observational design of the study and the use of hospital-based subjects may make our results more susceptible to bias (e.g., recall bias in collecting information on smoking retrospectively; underreporting of alcohol consumption; or selection bias). In order to minimize the potential selection bias, controls were selected among patients admitted with diagnoses in principle unrelated to exposures of interest. Even so, Campbell et al (2005) stated that European populations might show different levels of genetic substructure that could lead to false-positive associations as the result of population stratification [53]. In our study we controlled for that possibility with the inclusion of individuals from the same European ancestry (Caucasians). Regarding a potential misreporting of alcohol intake among cases and controls, if any, it should be non-differential and our effect estimates for alcohol consumption should be even stronger. The lack of information on alcohol consumption and dietary intake on one quarter of the study population was not related to the outcome and missing values were randomly distributed. However, it had reduced statistical power and the accuracy of estimates. Finally, the quite small sample size of some subgroups when analysis was stratified has prevented us from scoring statistically significance in them.
This work represents one of the few studies in which the effect of alcohol consumption on lung cancer risk was investigated beyond the tobacco smoking effect, and taking into account the Ile349Val polymorphism. To confirm or disregard our findings for the Ile349Val polymorphism, future studies should evaluate the effect of alcohol on lung cancer risk, undertaking assays of $\mathrm{ADH}$ activity and, if possible, exploring other polymorphisms potentially implicated in alcohol metabolism.

\section{Conclusions}

High alcohol consumption might have a slight effect on lung cancer development as well as a synergistic effect with tobacco. No clear association was found between alcohol consumption and lung cancer according to the Ile349Val polymorphism in ADH3 gene.

\section{Acknowledgments}

We are in debt to the patients who participated in the study. We are also grateful to Instituto Universitario de Oncología del Principado de Asturias (IUOPA).

This work was supported by Ministerio de Educación del Gobierno de España [AP2008-04284], Instituto de Salud Carlos III [FISS-PI060604], Fundación para el Fomento en Asturias de la Investigación Científica Aplicada y la Tecnología [FICYT IB09-133], CIBERESP and Obra Social Cajastur/Fundación Liberbank.

\section{Competing Interests}

The authors have declared that no competing interests exist.

\section{References}

1. Ferlay J, Soerjomataram I, Dikshit R, Eser S, Mathers C, Rebelo M, et al. Cancer incidence and mortality worldwide: sources, methods and major patterns in GLOBOCAN 2012. Int J Cancer. 2015; 136: E359-86.

2. [Internet] INE. Deaths according to Cause of Death. Instituto Nacional de Estadística (National Statistics Institute). http://www.ine.es/dyngs/ INEbase/en/operacion.htm?c=Estadistica_C\&cid $=1254736176780 \&$ menu=res ultados\&idp=1254735573175; 2014.

3. Baron O, Amini M, Duveau D, Despins P, Sagan CA, Michaud JL. Surgical resection of pulmonary metastases from colorectal carcinoma. Five-year survival and main prognostic factors. Eur J Cardiothorac Surg. 1996; 10: 347-51.

4. Praud D, Rota M, Rehm J, Shield K, Zatonski W, Hashibe M, et al. Cancer incidence and mortality attributable to alcohol consumption. Int J Cancer. 2016; 138: 1380-7.

5. IARC. Personal habits and indoor combustions. Volume $100 \mathrm{E}$. A review of human carcinogens. IARC monographs on the evaluation of carcinogenic risks to humans / World Health Organization, International Agency for Research on Cancer. 2012; 100: 1-538.

6. Wakai K, Nagata C, Mizoue T, Tanaka K, Nishino Y, Tsuji I, et al. Alcohol drinking and lung cancer risk: an evaluation based on a systematic review of epidemiologic evidence among the Japanese population. Jpn J Clin Oncol. 2007; 37: 168-74.

7. Freudenheim JL, Ram M, Nie J, Muti P, Trevisan M, Shields PG, et al. Lung cancer in humans is not associated with lifetime total alcohol consumption or with genetic variation in alcohol dehydrogenase 3 (ADH3). J Nutr. 2003; 133: 3619-24.

8. IARC. Alcohol drinking. Biological data relevant to the evaluation of carcinogenic risk to humans. IARC monographs on the evaluation of 
carcinogenic risks to humans / World Health Organization, International Agency for Research on Cancer. 1988; 44: 101-52.

9. IARC. Alcohol consumption and ethyl carbamate. IARC monographs on the evaluation of carcinogenic risks to humans / World Health Organization, International Agency for Research on Cancer. 2010; 96: 3-1383.

10. Edenberg HJ, Brown CJ, Hur MW, Kotagiri S, Li M, Zhang L, et al. Regulation of the seven human alcohol dehydrogenase genes. Adv Exp Med Biol. 1997; 414: 339-45.

11. Bosron WF, Li TK. Genetic polymorphism of human liver alcohol and aldehyde dehydrogenases, and their relationship to alcohol metabolism and alcoholism. Hepatology. 1986; 6: 502-10.

12. Boffetta P, Hashibe M. Alcohol and cancer. Lancet Oncol. 2006; 7: 149-56.

13. Eriksson CJ. The role of acetaldehyde in the actions of alcohol (update 2000). Alcohol Clin Exp Res. 2001; 25: 15S-32S

14. Singletary KW, Gapstur SM. Alcohol and breast cancer: review of epidemiologic and experimental evidence and potential mechanisms. JAMA. 2001; 286: 2143-51.

15. Coutelle C, Ward PJ, Fleury B, Quattrocchi P, Chambrin H, Iron A, et al. Laryngeal and oropharyngeal cancer, and alcohol dehydrogenase 3 and glutathione S-transferase M1 polymorphisms. Hum Genet. 1997; 99: 319-25.

16. Harty LC, Caporaso NE, Hayes RB, Winn DM, Bravo-Otero E, Blot WJ, et al. Alcohol dehydrogenase 3 genotype and risk of oral cavity and pharyngeal cancers. J Natl Cancer Inst. 1997; 89: 1698-705.

17. Bouchardy C, Hirvonen A, Coutelle C, Ward PJ, Dayer P, Benhamou S. Role of alcohol dehydrogenase 3 and cytochrome P-4502E1 genotypes in susceptibility to cancers of the upper aerodigestive tract. Int J Cancer. 2000; 87: 734-40.

18. Olshan AF, Weissler MC, Watson MA, Bell DA. Risk of head and neck cancer and the alcohol dehydrogenase 3 genotype. Carcinogenesis. 2001; 22: 57-61.

19. Sturgis EM, Dahlstrom KR, Guan Y, Eicher SA, Strom SS, Spitz MR, et al. Alcohol dehydrogenase 3 genotype is not associated with risk of squamous cell carcinoma of the oral cavity and pharynx. Cancer Epidemiol Biomarkers Prev. 2001; 10: 273-5.

20. Schwartz SM, Doody DR, Fitzgibbons ED, Ricks S, Porter PL, Chen C. Oral squamous cell cancer risk in relation to alcohol consumption and alcohol dehydrogenase-3 genotypes. Cancer Epidemiol Biomarkers Prev. 2001; 10: $1137-44$

21. Minegishi Y, Tsukino H, Muto M, Goto K, Gemma A, Tsugane S, et al. Susceptibility to lung cancer and genetic polymorphisms in the alcohol metabolite-related enzymes alcohol dehydrogenase 3, aldehyde dehydrogenase 2, and cytochrome P450 2E1 in the Japanese population. Cancer. 2007; 110: 353-62

22. Marin MS, Lopez-Cima MF, Garcia-Castro L, Pascual T, Marron MG, Tardon A. Poly (AT) polymorphism in intron 11 of the XPC DNA repair gene enhances the risk of lung cancer. Cancer Epidemiol Biomarkers Prev. 2004; 13: 1788-93.

23. Lopez-Cima MF, Gonzalez-Arriaga P, Garcia-Castro L, Pascual T, Marron MG, Puente XS, et al. Polymorphisms in XPC, XPD, XRCC1, and XRCC3 DNA repair genes and lung cancer risk in a population of northern Spain. BMC Cancer. 2007; 7: 162

24. Fernandez-Rubio A, Lopez-Cima MF, Gonzalez-Arriaga P, Garcia-Castro L, Pascual T, Marron MG, et al. The TP53 Arg72Pro polymorphism and lung cancer risk in a population of Northern Spain. Lung Cancer. 2008; 61: 309-16.

25. Gonzalez-Arriaga P, Lopez-Cima MF, Fernandez-Somoano A, Pascual T, Marron MG, Puente XS, et al. Polymorphism $+17 \mathrm{C} / \mathrm{G}$ in matrix metalloprotease MMP8 decreases lung cancer risk. BMC Cancer. 2008; 8: 378.

26. Leader A, Fernandez-Somoano A, Lopez-Cima MF, Gonzalez-Arriaga P, Pascual T, Marron MG, et al. Educational inequalities in quantity, duration and type of tobacco consumption among lung cancer patients in Asturias: epidemiological analyses. Psicothema. 2010; 22: 634-40.

27. Lopez-Cima MF, Alvarez-Avellon SM, Pascual T, Fernandez-Somoano A, Tardon A. Genetic polymorphisms in CYP1A1, GSTM1, GSTP1 and GSTT1 metabolic genes and risk of lung cancer in Asturias. BMC Cancer. 2012; 12: 433.

28. Gonzalez-Arriaga P, Pascual T, Garcia-Alvarez A, Fernandez-Somoano A, Lopez-Cima MF, Tardon A. Genetic polymorphisms in MMP 2, 9 and 3 genes modify lung cancer risk and survival. BMC Cancer. 2012; 12: 121.

29. Vlaanderen J, Portengen L, Schuz J, Olsson A, Pesch B, Kendzia B, et al. Effect modification of the association of cumulative exposure and cancer risk by intensity of exposure and time since exposure cessation: a flexible method applied to cigarette smoking and lung cancer in the SYNERGY Study. Am J Epidemiol. 2014; 179: 290-8

30. Bigert C, Gustavsson P, Straif K, Pesch B, Bruning T, Kendzia B, et al. Lung cancer risk among cooks when accounting for tobacco smoking: a pooled analysis of case-control studies from Europe, Canada, New Zealand, and China. J Occup Environ Med. 2015; 57: 202-9.

31. Willett WC, Sampson L, Stampfer MJ, Rosner B, Bain C, Witschi J, et al. Reproducibility and validity of a semiquantitative food frequency questionnaire. Am J Epidemiol. 1985; 122: 51-65.

32. Vioque J, Gonzalez L. Validity of a food frequency questionnaire (preliminary results). European Journal of Cancer Prevention. 1991; 1: 19

33. Vioque J, Navarrete-Munoz EM, Gimenez-Monzo D, Garcia-de-la-Hera M, Granado F, Young IS, et al. Reproducibility and validity of a food frequency questionnaire among pregnant women in a Mediterranean area. Nutr J. 2013; 12: 26.
34. Vioque J, Weinbrenner T, Asensio L, Castello A, Young IS, Fletcher A. Plasma concentrations of carotenoids and vitamin $\mathrm{C}$ are better correlated with dietary intake in normal weight than overweight and obese elderly subjects. Br J Nutr. 2007; 97: 977-86.

35. Palma I, Farran A, Cantos D. Tablas de composición de Alimentos por medidas caseras de consumo habitual en España. Madrid. Mc Graw Hill Interamerican; 2008.

36. [Internet] USDA. USDA National Nutrient Database for Standard Reference, Release 25. US Department of Agriculture: Agricultural Research Service. https://www.ars.usda.gov/research/publications/publication/?seqNo115= 285841; 2012.

37. Block G, Hartman AM, Naughton D. A reduced dietary questionnaire: development and validation. Epidemiology. 1990; 1: 58-64.

38. Ocke MC, Bueno-de-Mesquita HB, Pols MA, Smit HA, van Staveren WA, Kromhout D. The Dutch EPIC food frequency questionnaire. II. Relative validity and reproducibility for nutrients. Int J Epidemiol. 1997; 26 Suppl 1: S49-58.

39. Subar AF, Thompson FE, Kipnis V, Midthune D, Hurwitz P, McNutt S, et al. Comparative validation of the Block, Willett, and National Cancer Institute food frequency questionnaires : the Eating at America's Table Study. Am J Epidemiol. 2001; 154: 1089-99.

40. Willett W. Nutritional Epidemiology. 3 Edition.: Oxford. New York: Oxford University Press; 2012.

41. Vioque J, Egea CM, Porta M. Stomach cancer mortality in Spain: an ecological analysis of diet, altitude, latitude, and income. J Epidemiol Community Health. 1995; 49: 441-2

42. Miller SA, Dykes DD, Polesky HF. A simple salting out procedure for extracting DNA from human nucleated cells. Nucleic Acids Res. 1988; 16: 1215.

43. Wolf FM. Meta-analysis: quantitative methods for research synthesis. Beverly Hills, Sage Publications; 1986.

44. Yamamoto K, Ueno Y, Mizoi Y, Tatsuno Y. Genetic polymorphism of alcohol and aldehyde dehydrogenase and the effects on alcohol metabolism. Arukoru Kenkyuto Yakubutsu Ison. 1993; 28: 13-25.

45. Yang M, Coles BF, Delongchamp R, Lang NP, Kadlubar FF. Effects of the ADH3, CYP2E1, and GSTP1 genetic polymorphisms on their expressions in Caucasian lung tissue. Lung Cancer. 2002; 38: 15-21.

46. Seitz HK, Becker P. Alcohol metabolism and cancer risk. Alcohol Res Health. 2007; 30: 38-41, 4-7.

47. Brennan P, Lewis S, Hashibe M, Bell DA, Boffetta P, Bouchardy C, et al. Pooled analysis of alcohol dehydrogenase genotypes and head and neck cancer: a HuGE review. Am J Epidemiol. 2004; 159: 1-16.

48. Yokoyama A, Kato H, Yokoyama T, Tsujinaka T, Muto M, Omori T, et al. Genetic polymorphisms of alcohol and aldehyde dehydrogenases and glutathione S-transferase M1 and drinking, smoking, and diet in Japanese men with esophageal squamous cell carcinoma. Carcinogenesis. 2002; 23: 1851-9.

49. Rohrmann S, Linseisen J, Boshuizen HC, Whittaker J, Agudo A, Vineis P, et al. Ethanol intake and risk of lung cancer in the European Prospective Investigation into Cancer and Nutrition (EPIC). Am J Epidemiol. 2006; 164: 1103-14

50. Bandera EV, Freudenheim JL, Vena JE. Alcohol consumption and lung cancer: a review of the epidemiologic evidence. Cancer Epidemiol Biomarkers Prev. 2001; 10: 813-21.

51. Korte JE, Brennan P, Henley SJ, Boffetta P. Dose-specific meta-analysis and sensitivity analysis of the relation between alcohol consumption and lung cancer risk. Am J Epidemiol. 2002; 155: 496-506.

52. Freudenheim JL, Ritz J, Smith-Warner SA, Albanes D, Bandera EV, van den Brandt PA, et al. Alcohol consumption and risk of lung cancer: a pooled analysis of cohort studies. Am J Clin Nutr. 2005; 82: 657-67.

53. Campbell CD, Ogburn EL, Lunetta KL, Lyon HN, Freedman ML, Groop LC, et al. Demonstrating stratification in a European American population. Nat Genet. 2005; 37: 868-72. 